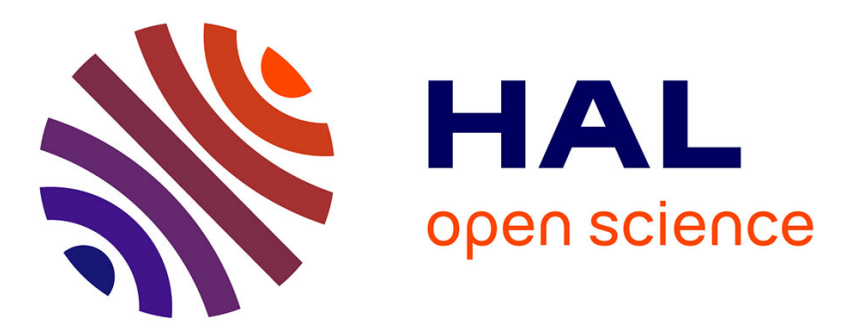

\title{
Mediation and Meaning in HCI
}

\author{
Susanne Bødker, Olav W. Bertelsen, Liam Bannon, Clarisse De Souza, Simone \\ Barbosa, Raquel Prates
}

\section{To cite this version:}

Susanne Bødker, Olav W. Bertelsen, Liam Bannon, Clarisse De Souza, Simone Barbosa, et al.. Mediation and Meaning in HCI. 15th Human-Computer Interaction (INTERACT), Sep 2015, Bamberg, Germany. pp.667-668, 10.1007/978-3-319-22723-8_93 . hal-01610826

\section{HAL Id: hal-01610826 \\ https://hal.inria.fr/hal-01610826}

Submitted on 5 Oct 2017

HAL is a multi-disciplinary open access archive for the deposit and dissemination of scientific research documents, whether they are published or not. The documents may come from teaching and research institutions in France or abroad, or from public or private research centers.
L'archive ouverte pluridisciplinaire HAL, est destinée au dépôt et à la diffusion de documents scientifiques de niveau recherche, publiés ou non, émanant des établissements d'enseignement et de recherche français ou étrangers, des laboratoires publics ou privés. 


\title{
Mediation and Meaning in HCI
}

\author{
Susanne Bødker ${ }^{1}$, Olav W. Bertelsen ${ }^{1}$, Liam Bannon ${ }^{2}$, Clarisse de Souza ${ }^{3}$, \\ Simone Barbosa ${ }^{3}$ and Raquel Prates ${ }^{4}$ \\ ${ }^{1}$ Aarhus University, Aarhus, Denmark \\ \{bodker,olavb\}@cs.au.dk \\ ${ }^{2}$ University of Limerick, Limerick, Ireland \\ \{liambannon@gmail.com\} \\ ${ }^{3}$ Pontifical Catholic University, Rio de Janeiro, Brazil \\ \{clarisse,simone\}@inf.puc-rio.br \\ ${ }^{4}$ Federal University of Minas Gerais, Belo Horizonte, Brazil \\ rprates@dcc.ufmg.br
}

This workshop is about computer mediation in human communication and action. The proponents all look at mediation from different angles, but share the view that meaning is what mediation is about. We aim to dig beneath the surface and touch on the conception, construction, negotiation and evolution of meaning in and of technology, for producers and consumers, before and after technology is deployed. Mediation and meaning will thus allow us to discuss how different segments and perspectives in HCI research can be brought together to give us new insights about how people interact with technology.

The workshop will start with three discussion scenarios that the proponents will provide. Meaning conception, for example, will be initially discussed against the backdrop of participatory design $[4,5]$, which accounts for what producers (including owners) and consumers mean when they talk about some specific technology that is being created. Meaning construction, in turn, is the focus of semiotic engineering [3], which accounts for how meaning and intent are communicated through technologies and their interfaces. It involves, once again, producers (namely, designers and developers) and consumers (namely end-users and/or application developers and tailors). Finally, meaning evolution gives rise to discussions of technology appropriation and mediation in social activities $[1,2]$ as well as user-driven technology adaptation and extension [6]. The interest of the proposed approach to the workshop is that not only do the three scenarios highlight the dependency between meaning conception, creation and evolution, but they will also highlight the shapes that meaning negotiation can take. In meaning negotiation, specifically, mediation artifacts and processes play a fundamental role, both between different groups of people and between people and technology.

We invite and expect contributions coming from theories, approaches, methods and empirical studies that focus on computing technology as mediators of human action and activity, that is, that can view HCI as interaction between human beings through computers. Some other related areas, in addition to the ones already mentioned, include, but are not limited to, computer semiotics, activity theory, metadesign, (micro and macro) cultural adaptation, IT adoption and appropriation.

We propose a one-day workshop based on accepted contributions. We will call for position paper submissions that address mediated meaning in use and design of com- 
puter technology, focusing on HCI theory (or theoretical approaches), methods or practical aspects (like empirical cases and examples in design or evaluation). They are reviewed by the organizers and serve as foundation of the workshop. Workshop position papers are published in the official adjunct proceedings. Workshop position papers should have a length of 4 to 6 pages. The workshop website can be found at http://pit.au.dk/news-events/events/upcoming-events/interact-2015-ws-mediationand-meaning-in-hci/.

\section{References}

1. Bødker, S. \& Bøgh Andersen, P. (2005). Complex Mediation, Journal of Human Computer Interaction, 20(4), pp. 353-402.

2. Bryant, S.L. Forte, A. and Bruckman, A. (2005). Becoming Wikipedian: transformation of participation in a collaborative online encyclopedia. GROUP'05. $1-10$.

3. de Souza, C.S. (2005) The semiotic engineering of human-computer interaction. Cambridge, Mass. The MIT Press.

4. Dindler, D..and Iversen, O. S. (2014). Relational expertise in participatory design. PDC '14, Vol. 1, 41-50.

5. Greenbaum, J. \& Kyng, M. (eds.). (1991). Design at Work: Cooperative Design of Computer Systems. Hillsdale, NJ. Lawrence Erlbaum Associates.

6. Lieberman, H., Paternò, F. and Wulf, V. (2006). End User Development. Heidelberg. Springer.

\section{About the Organizers}

Susanne Bødker is Professor of Human-Computer Interaction at the Department of Computer Science, Aarhus University. She works with activity theoretical HCI, Participatory Design and Computer Supported Cooperative Work.

Olav W. Bertelsen is Associate Professor of Human-Computer Interaction at the Department of Computer Science, Aarhus University. He works with materialist and pragmatist approaches to technologies in human life.

Liam Bannon is affiliated with the Dept. of Computer Science \& Information Systems, University of Limerick and the Department of Computer Science, Aarhus University. He does research in interaction design and CSCW.

Clarisse de Souza is Full Professor at the Informatics Department, PUC-Rio. She created Semiotic Engineering, a semiotic theory of HCI. Her research interests center on meaning negotiation and evolution in human-computer interaction.

Simone Barbosa works at PUC-Rio in the area of Human-Computer Interaction, as seen from a Semiotic Engineering perspective. Her research interests involve: model-based interactive systems design; bridging HCI and software engineering.

Raquel Prates is an Associate professor at the Computer Science Department at the Federal University of Minas Gerais (UFMG) in Brazil. She works with HCI and Collaborative Systems and interests include Semiotic Engineering and sociability. 